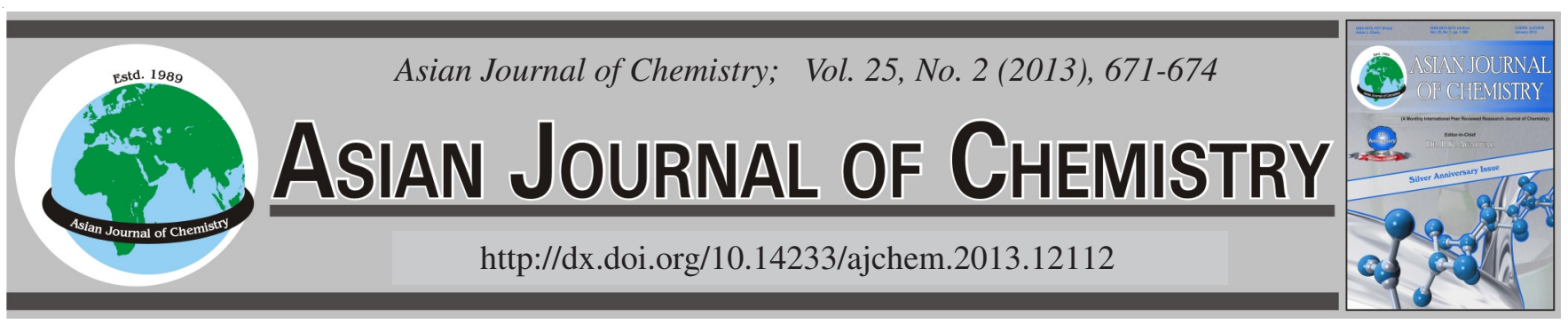

\title{
Analysis of Essential Oil from Pericarps of Chimonanthus praecox
}

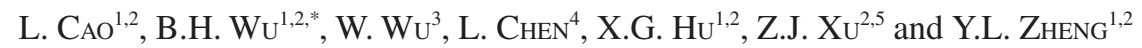

${ }^{1}$ Triticeae Research Institute, Sichuan Agricultural University, Wenjiang 611130, P.R. China

${ }^{2}$ Key Laboratory of Crop Genetic Resources and Improvement, Ministry of Education/Sichuan Agricultural University, Ya'an 625014, P.R. China ${ }^{3}$ Agronomy College, Sichuan Agricultural University, Wenjiang 611130, P.R. China

${ }^{4}$ Food Science College, Sichuan Agricultural University, Ya'an 625014, P.R. China

${ }^{5}$ Rice Research Institute, Sichuan Agricultural University, Wenjiang 611130, P.R. China

*Corresponding author: Fax: +86 28 82650350; Tel: +8628 82650313; E-mail: wubihua2001@yahoo.com.cn

Key Words: Chimonanthus praecox, Pericarp, Essential oil, Hydrodistillation, Gas chromatography-mass spectrometry.

ᄂ - - - - - - - - - - - - - - - - - - - - - - - - - -

\section{INTRODUCTION}

Chimonanthus praecox (L.) Link, belonging to the Calycanthaceae family, is a deciduous shrub native to China, which has survived from the tertiary relic period ${ }^{1}$. It has been called by various synonyms such as Gol-e Yakh in Iran, Roubai in Japan, Lamei in China and wintersweet in England ${ }^{2}$. It is a famous traditional fragrant flower plant with high ornamental value in China. The flowers, leaves, fruits and roots of wintersweet are also a Chinese folk herbal medicine for the treatment of colds, rheumatoid pains, coughs, asthma and other disorders $^{2-6}$.

In recent years, developing the essential oil production of wintersweet has been more and more attended due to the excellent aroma ${ }^{1}$. Some researchers have investigated the essential oils in wintersweet flowers ${ }^{2,7}$. However, less information has been reported on essential oil in pericarps of both wild and cultivated wintersweets. The information on essential oil and its chemical component in wintersweet pericarps is important to better understanding the pericarp aromatic and medical properties and to utilizing it in the fragrant and medicinal industries in addition to probing the developing relationship of oil vacuoles between the pericarps and the flowers, because the fruits are further developed from the flowers. The objectives of this study are to extract the essential oil in pericarps from both wild and cultivated wintersweets with steam distillation and analyze the chemical components with GC-MS and to compare the characteristics of essential oil between them for more effectively researching and developing the special products of wintersweet plants.

\begin{tabular}{l} 
EXPERIMENTAL \\
\hline The wild wintersweet (Chimonanthus praecox) plants \\
and flowers are with red or purple speckles on the inside \\
perianths, were randomly selected at the Taipingzhen and \\
Qinghuazhen of Wanyuan, Sichuan, China, respectively. And, \\
the ornamental cultivar Suxinlamei with perfect yellow \\
flowers grown at the Taipingzhen was used for the control. \\
The mature and dried fruits were picked from the plants. The \\
pericarps were separated from the seeds by hands and then \\
pulverized for $0.85 \mathrm{~mm}$ using the vegetation disintegrator \\
FW100.
\end{tabular}


Essential oil extraction: $50 \mathrm{~g}$ pericarpic powders were weighed and placed in a clevenger apparatus, then distilled water for $450 \mathrm{~mL}$ was infused. The essential oil was extracted by hydrodistillation for $2.5 \mathrm{~h}$ as the method in Pharmacopoeia of the People's Republic of China (2005). The essential oil was collected in EP (eppendorf) tubes using micropipettor and dried by anhydrous sodium sulphate and stored in ultra low temperature freezer at $-80^{\circ} \mathrm{C}$ until chemically analyzed.

GC-MS analysis: To detect the chemical components of essential oil, GC-MS (gas chromatography-mass spectrometry) analysis was performed on an Agilent 5973N MS system coupled with an HP 6890 gas chromatograph, equipped with fused silica capillary column coated with $5 \%$ phenyl methyl siloxane methyl silicone (HP-5MS), $30 \mathrm{~m} \times 0.25 \mathrm{~mm}$, film thickness $0.25 \mu \mathrm{m}$. Analytical conditions were as follows: the carrier gas was helium at $1 \mathrm{~mL} / \mathrm{min}$ and injection volume of each sample was $1 \mu \mathrm{L}$ and split ratio was 1:50. The injection port and the detector temperatures were 250 and $280{ }^{\circ} \mathrm{C}$, respectively. Oven temperature was programmed as follows: the column temperature was programmed from 60 to $130{ }^{\circ} \mathrm{C}$ at a rate of $10{ }^{\circ} \mathrm{C} / \mathrm{min}$, isothermal at $130{ }^{\circ} \mathrm{C}$ for $16 \mathrm{~min}$, then increased to $250{ }^{\circ} \mathrm{C}$ at a rate of $10^{\circ} \mathrm{C} / \mathrm{min}$ and subsequently held isothermal for $16 \mathrm{~min}$. Ionization of the sample components was performed in the EI mode $(70 \mathrm{eV})$.

Identification of components: The GC-MS data were processed using the Agilent MSD Productivity ChemStation Software. The individual components were identified by comparing their mass spectra and retention indices with those reported in the literatures or stored in the NIST02 and NIST05 versions of mass spectral database (National Institute of Standards and Technology, Washington, DC, USA), respectively. Retention indices were calculated using retention times of $n$-alkanes that were injected under the same chromatographic conditions as the essential oil analysis.

\section{RESULTS AND DISCUSSION}

Yield of the essential oils: Pale yellow essential oil was obtained from both the cultivated and wild wintersweet pericarps by hydrodistillation. The obvious differences of essential oil yield were observed between the different wild wintersweet accessions, and between wild and cultivated plants. The wild wintersweet pericarps at Qinghuazhen produced higher essential oil yield for $0.23 \%$ than that at Taipingzhen for $0.17 \%$, both of which yielded more essential oil than that of the cultivar Suxinlamei, only for $0.12 \%$ (Table-1).

Chemical components of the essential oils: The differences of chemical components of the essential oils existed between the wild wintersweets of the two analyzed areas, as well as between the wild and cultivated materials (Table-2). Sixty-six and fifty-one peaks were obtained in the total ion chromatogram of chemical components of the essential oils in wild wintersweet pericarps at Qinghuazhen and Taipingzhen, respectively, while 48 peaks of the essential oil in the cultivar Suxinlamei (Fig. 1). A total of 37 chemical components were identified, accounting for $74.05 \%$ of the total volatiles of the wild plant at Qinghuazhen, more than and covered all the 29 components accounting for $67.3 \%$ of that at Taipingzhen, both of which were more than that of cultivar Suxinlamei with 21 components accounting for $73.98 \%$. Of which, 19 were shared by the wild and cultivated wintersweets (Table-2).
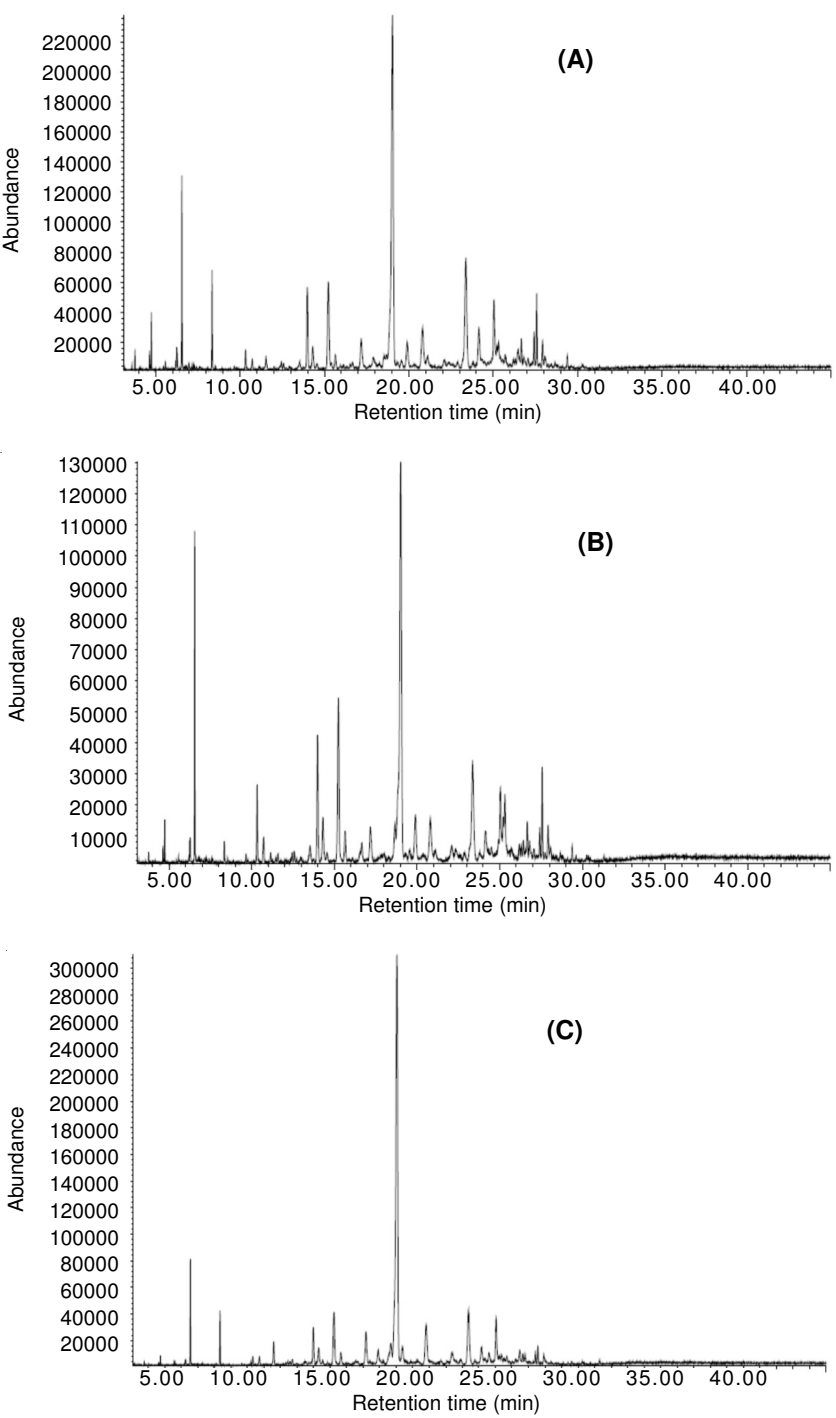

Fig. 1. Total ion chromatogram of chemical components of essential oil in pericarps of the analyzed wintersweets ((A) Wild wintersweet at Qinghuazhen, (B) Suxinlamei, (C) wild wintersweet at Taipingzhen)

TABLE-1

YIELD AND TYPES OF CHEMICAL COMPONENTS OF ESSENTIAL OIL IN PERICARPS OF THE ANALYZED WINTERSWEETS (\%)

\begin{tabular}{|c|c|c|c|c|}
\hline \multirow{2}{*}{\multicolumn{2}{|c|}{ Essential oil }} & \multirow{2}{*}{ Suxinlamei } & \multicolumn{2}{|c|}{ Wild wintersweet } \\
\hline & & & Taipingzhen & Qinghuazhen \\
\hline \multicolumn{2}{|c|}{ Yield (\%) } & 0.12 & 0.17 & 0.23 \\
\hline \multirow{4}{*}{$\begin{array}{l}\text { Types of chemical } \\
\text { components }\end{array}$} & Monoterpenoids & 4.666 & 3.386 & 8.213 \\
\hline & Sesquiterpenoids & 67.528 & 60.474 & 60.468 \\
\hline & Aromatics & Not detected & 0.034 & 0.094 \\
\hline & Aliphatics & 1.787 & 2.991 & 4.273 \\
\hline
\end{tabular}




\begin{tabular}{|c|c|c|c|c|c|c|c|c|}
\hline \multirow{3}{*}{ No. } & \multicolumn{8}{|c|}{$\begin{array}{c}\text { TABLE-2 } \\
\text { CHEMICAL COMPONENTS AND THEIR CONTENT OF ESSENTIAL } \\
\text { OIL IN PERICARPS FROM THE ANALYZED WINTERSWEETS }\end{array}$} \\
\hline & \multirow{2}{*}{$\begin{array}{l}\text { Retention } \\
\text { time (min) }\end{array}$} & \multirow{2}{*}{ Component } & \multirow{2}{*}{ RI } & \multirow{2}{*}{ Formula } & \multirow{2}{*}{ m.w. } & \multirow{2}{*}{ Suxinlamei $^{\mathrm{a}}$} & \multicolumn{2}{|c|}{ Wild wintersweet ${ }^{\mathrm{a}}$} \\
\hline & & & & & & & Qinghuazhen & Taiping zhen \\
\hline 1 & 3.594 & Pinene & 930.1 & $\mathrm{C}_{10} \mathrm{H}_{16}$ & 136 & $-^{\mathrm{b}}$ & 0.063 & - \\
\hline 2 & 3.771 & Camphene & 944.4 & $\mathrm{C}_{10} \mathrm{H}_{16}$ & 136 & 0.071 & 0.256 & 0.039 \\
\hline 3 & 4.091 & Sabinene & 970.2 & $\mathrm{C}_{10} \mathrm{H}_{16}$ & 136 & - & 0.03 & - \\
\hline 4 & 4.64 & Dolcymene & 1014.6 & $\mathrm{C}_{10} \mathrm{H}_{14}$ & 134 & 0.07 & 0.27 & 0.049 \\
\hline 5 & 4.697 & Limonene & 1019.2 & $\mathrm{C}_{10} \mathrm{H}_{18} \mathrm{O}$ & 154 & - & 0.049 & - \\
\hline 6 & 4.743 & Eucalyptol & 1023.1 & $\mathrm{C}_{10} \mathrm{H}_{16}$ & 136 & 0.202 & 0.802 & 0.118 \\
\hline 7 & 5.577 & Linalool & 1090.5 & $\mathrm{C}_{10} \mathrm{H}_{18} \mathrm{O}$ & 154 & 0.128 & 0.143 & 0.051 \\
\hline 8 & 6.194 & L-pinocarveol & 1136.2 & $\mathrm{C}_{10} \mathrm{H}_{16} \mathrm{O}$ & 152 & - & 0.179 & - \\
\hline 9 & 6.246 & Berbenol & 1140 & $\mathrm{C}_{10} \mathrm{H}_{16} \mathrm{O}$ & 152 & 0.126 & 0.378 & 0.18 \\
\hline 10 & 6.28 & Camphor & 1142.4 & $\mathrm{C}_{10} \mathrm{H}_{16} \mathrm{O}$ & 152 & 0.126 & 0.261 & 0.139 \\
\hline 11 & 6.554 & Borneol & 1162.1 & $\mathrm{C}_{10} \mathrm{H}_{18} \mathrm{O}$ & 154 & 2.379 & 3.266 & 1.991 \\
\hline 12 & 6.783 & Benzenemethanol, $\alpha, \alpha, 4$-trimethyl- & 1178.6 & $\mathrm{C}_{10} \mathrm{H}_{14} \mathrm{O}$ & 150 & - & 0.094 & 0.034 \\
\hline 13 & 6.834 & Cryptone & 1182.6 & $\mathrm{C}_{9} \mathrm{H}_{14} \mathrm{O}$ & 138 & - & 0.101 & - \\
\hline 14 & 6.966 & Myrtenol & 1193.1 & $\mathrm{C}_{10} \mathrm{H}_{16} \mathrm{O}$ & 152 & - & 0.204 & - \\
\hline 15 & 7.16 & Berbenone & 1205 & $\mathrm{C}_{10} \mathrm{H}_{14} \mathrm{O}$ & 150 & - & 0.09 & 0.051 \\
\hline 16 & 7.246 & trans-Carveol & 1210.2 & $\mathrm{C}_{10} \mathrm{H}_{16} \mathrm{O}$ & 152 & - & 0.098 & 0.049 \\
\hline 17 & 7.595 & D-Carvone & 1230.6 & $\mathrm{C}_{10} \mathrm{H}_{14} \mathrm{O}$ & 150 & - & 0.038 & - \\
\hline 18 & 8.343 & Borneol acetate & 1275.8 & $\mathrm{C}_{12} \mathrm{H}_{20} \mathrm{O}_{2}$ & 196 & 1.564 & 2.01 & 0.663 \\
\hline 19 & 8.538 & Thymol & 1287.4 & $\mathrm{C}_{10} \mathrm{H}_{14} \mathrm{O}$ & 150 & - & 0.076 & 0.056 \\
\hline 20 & 10.218 & Ylangene & 1358.9 & $\mathrm{C}_{15} \mathrm{H}_{24}$ & 204 & 0.148 & - & - \\
\hline 21 & 10.332 & $\alpha$-Cubebene & 1363.4 & $\mathrm{C}_{15} \mathrm{H}_{24}$ & 204 & - & 0.507 & 0.525 \\
\hline 22 & 10.727 & $\beta$-Elemene & 1379.2 & $\mathrm{C}_{15} \mathrm{H}_{24}$ & 204 & - & 0.385 & 0.326 \\
\hline 23 & 11.538 & Santalene & 1407.1 & $\mathrm{C}_{15} \mathrm{H}_{24}$ & 204 & - & 0.571 & 0.6 \\
\hline 24 & 12.447 & Chamigrene & 1429.9 & $\mathrm{C}_{15} \mathrm{H}_{24}$ & 204 & - & 0.265 & 0.262 \\
\hline 25 & 12.573 & $\alpha$-Gurjunene & 1433.2 & $\mathrm{C}_{15} \mathrm{H}_{24}$ & 204 & - & 0.237 & 0.203 \\
\hline 26 & 12.727 & Humulene & 1436.9 & $\mathrm{C}_{15} \mathrm{H}_{24}$ & 204 & 0.309 & - & - \\
\hline 27 & 13.984 & Eudesma-4(14),11-diene & 1468.2 & $\mathrm{C}_{15} \mathrm{H}_{24}$ & 204 & 2.216 & 3.71 & 2.962 \\
\hline 28 & 14.31 & Germacrene D & 1476.9 & $\mathrm{C}_{15} \mathrm{H}_{24}$ & 204 & 1.293 & 1.279 & 1.263 \\
\hline 29 & 14.562 & $\alpha$-Muurolene & 1482.9 & $\mathrm{C}_{15} \mathrm{H}_{24}$ & 204 & 0.29 & 0.325 & 0.316 \\
\hline 30 & 15.236 & $\gamma$-Cadinene & 1499.5 & $\mathrm{C}_{15} \mathrm{H}_{24}$ & 204 & 4.744 & 5.619 & 5.712 \\
\hline 31 & 17.888 & Nerolidol & 1540 & $\mathrm{C}_{15} \mathrm{H}_{26} \mathrm{O}$ & 222 & 1.254 & 1.124 & 0.834 \\
\hline 32 & 19.031 & Caryophyllene oxide & 1557.3 & $\mathrm{C}_{15} \mathrm{H}_{24} \mathrm{O}$ & 220 & 45.71 & 28.517 & 30.826 \\
\hline 33 & 19.905 & Carotol & 1570.4 & $\mathrm{C}_{15} \mathrm{H}_{26} \mathrm{O}$ & 222 & - & 1.757 & 1.27 \\
\hline 34 & 20.82 & $\begin{array}{l}\text { 1,5,5,8-Tetramethyl-12-oxabicyclo[9.1.0 } \\
\text { dodeca-3,7-diene \# }\end{array}$ & 1584.6 & $\mathrm{C}_{15} \mathrm{H}_{24} \mathrm{O}$ & 220 & 4.286 & 3.475 & 3.546 \\
\hline 35 & 23.38 & T-Cadinol & 1630.2 & $\mathrm{C}_{15} \mathrm{H}_{26} \mathrm{O}$ & 222 & 6.035 & 9.265 & 8.392 \\
\hline 36 & 24.152 & Viridiflorol & 1645.1 & $\mathrm{C}_{15} \mathrm{H}_{26} \mathrm{O}$ & 222 & 1.787 & 3.03 & 2.991 \\
\hline 37 & 27.421 & Nootkatone & 1721.9 & $\mathrm{C}_{15} \mathrm{H}_{22} \mathrm{O}$ & 218 & 0.504 & 1.175 & 1.304 \\
\hline 38 & 27.57 & Aristolone & 1728.6 & $\mathrm{C}_{15} \mathrm{H}_{22} \mathrm{O}$ & 218 & 0.739 & 2.257 & 2.133 \\
\hline 39 & 27.924 & $\begin{array}{l}\text { 7-Methyl-4-(1-methylethylidene)bicyclo } \\
\text { [5.3.1] undec-1-en-8-ol \# }\end{array}$ & 1744.5 & $\mathrm{C}_{15} \mathrm{H}_{24} \mathrm{O}$ & 220 & - & 1.142 & - \\
\hline
\end{tabular}

Retention index (RI) according to C8-C40 $n$-alkanes on the HP-5MS column in parentheses. ${ }^{a}$ Relative content (\%). ${ }^{b}$ Not detected.

The similar preponderant types but the different number and relative content of the components among the analyzed materials were observed (Table-2). The wild wintersweet at Qinghuazhen was with the main components accounting for $61.15 \%$ including caryophyllene oxide $(28.52 \%)$, T-cadinol $(9.27 \%), \gamma$-cadinene $(5.62 \%)$, eudesma-4(14), 11-diene (3.71\%), 1,5,5,8-tetramethyl-12-oxabicyclo[9.1.0]dodeca-3,7diene\# (3.48\%), borneol (3.27\%), viridiflorol (3.03\%), aristolone $(2.26 \%)$, borneol acetate $(2.01 \%)$. The wild plant at Taipingzhen had the main components for $56.56 \%$ consisting of caryophyllene oxide (30.83\%), T-cadinol (8.38\%), $\gamma$ cadinene $(5.71 \%), 1,5,5,8$-tetramethyl-12-oxabicyclo[9.1.0] dodeca-3,7-diene\# (3.55\%), viridiflorol (2.99\%), eudesma4(14),11-diene $(2.96 \%)$, aristolone $(2.13 \%)$. And, the cultivar Suxinlamei was with these for $65.37 \%$ comprising caryophyllene oxide (45.71\%), T-cadinol (6.04\%), $\gamma$-cadinene (4.74\%),1,5,5,8-tetramethyl-12-oxabicyclo[9.1.0]dodeca-3,7diene\# (4.29\%), borneol (2.38\%), eudesma-4(14),11-diene $(2.22 \%)$.

The maximum component, caryophyllene oxide of the essential oil, has high value in medicinal properties. It has antitumor activities ${ }^{8}$, antispasmodic ${ }^{9}$ and antimalarial effects ${ }^{10}$ and is able to resist some stubborn bacterials like Staphyloccocus aureus $^{11}$. Likewise, T-cadinol, the second preponderant component of the essential oil, has many healing properties like relaxing smooth muscle, treating diarrhea, inhibiting duodenal juices accumulation caused by cholera toxin in mouse ${ }^{12}$, having calcium antagonistic effect ${ }^{13}$ and bactericidal effect $^{14}$ and other bioactivities like killing mite worm ${ }^{15}$. Apparently, the essential oil of wintersweet pericarps possesses high medicinal value and therefore, is worthwile for further research and development. 
Types of chemical components of the essential oils: The major chemical components of essential oils in pericarps from both the two wild and cultivated wintersweet were terpenes, which were primarily characterized by sesquiterpenoids, accounting for $60.474,60.468$ and $67.528 \%$, respectively. It might be associated with the close genetic relationship between them because of the cultivar Suxinlamei with perfect yellow flowers being the mutant from wild wintersweet with purple or red speckles' flowers. These results revealed that the oil vacuole tissues of wintersweet flowers might be further developed to the fruits, even kept within the dried pericarps that are developed from the ovary walls, which implied that there are probably abundant oil vacuole cells in the pistil of wintersweet.

However, some obvious differences existed in between the wild and cultivated wintersweets as well as the wild wintersweets (Table-1). The aromatics existing in the wild wintersweets, were not observed in the cultivar Suxinlamei. And, there were more abundant aliphatics in the wild wintersweets $(2.991$ and $4.273 \%$ ) than in the cultivar Suxinlamei $(1.787 \%)$. In addtion, the monoterpenoids, aliphatics and aromatics in the wild winteersweet at Qinghuazhen were 2.4, 1.4 and 2.8 times more than those at Taipingzhen, respectively.

The wild wintersweet pericarps from the two different areas produced higher yield and contained more abundant chemical components of essential oil than the cultivated Suxinlamei ones, though the wild wintersweet lacked of the two components Ylangene and Humulene of cultivated wintersweet. These results suggested that partial genetic materials controlling some particular natural products might be varied and lost in the processes of evolution and domestication from wild to cultivated wintersweet. It is possible to breed more excellent wintersweet cultivars with both higher yield and more abundant chemical components of essential oil in pericarps by the genetic recombination between wild and cultivated wintersweets, which might enjoy the ornamental in winter as well as provide the raw and processed materials for essential oil and medicinal industries in summer.
The yield and chemical components of essential oil between the tested wild wintersweet pericarps were outstandingly different. The wild wintersweet pericarps contained higher yield and more abundant chemical components at Qinghuazhen than that at Taipingzhen, which might be associated with both the genetic and environmental factors. So, it is possible to explore better genetic resources in different wild wintersweet populations.

\section{ACKNOWLEDGEMENTS}

This research was supported by the Project-sponsored by SRF for ROCS, SEM and the Research Grants for the Dabashan Wintersweet in Wanyuan of Sichuan, China.

\section{REFERENCES}

1. J. Ming and H.R. Liao, J. Beijing Forestry Univ. (Soc. Sc.), 3, 60 (2004).

2. Y. Ueyama, S. Hashimoto, H. Nii and K. Furukawa, Flavour Fragr. J., 5, 85 (1990).

3. Y.Q. Zheng, Y. Zhu, R. Zhang, Y. Sun, Z. Wu and M. Liu, Acta Sci. Nat. Univ. Pekin, 26, 667 (1990).

4. H.R. Zhao, Q.F. Ji, M.S. Wang, S.X. Zhao and Y.P. Wang, J. China Pharm. Univ., 24, 76 (1993).

5. B.K. Xiao and Y.M. Liu, Res. Practice Chin. Med., 17, 59 (2003).

6. Y.Q. Xiong, C. Xiao and X.J. Long, Chin. Wild Plant Resour., 27, 8 (2008).

7. J. Wu, B.-H. Wu, L. Cao, X.-G. Hu, Z.-J. Xu and Y.-L. Zheng, Asian J. Chem., 24, 1563 (2012).

8. G.Q. Zheng, P.M. Kenney and L.K. Lam, J. Nat. Prod., 55, 999 (1992).

9. M. Shimizu, H. Shogawa, T. Matsuzawa, S. Yonezawa, T. Hayashi, M. Arisawa, S. Suzuki, M. Yoshizaki, N. Morita, E. Ferro, I. Basualdo and L.H. Berganza, Chem. Pharm. Bull., 38, 2283 (1990).

10. C. Thebtaranonth, Y. Thebtaranonth, S. Wanauppathamkul and Y. Yuthavong, Phytochemistry, 40, 125 (1995).

11. A. Ulubelen, G. Topcu, C. Eri, U. Sönmez, M. Kartal, S. Kurucu and C. Bozok-Johansson, Phytochemistry, 36, 971 (1994).

12. P. Claeson, R. Andersson and G. Samuelsson, Plant Med., 57, 352 (1991).

13. P. Claeson, P. Zygmunt and E.D. Högestätt, Pharm. Toxicol., 69, 173 (1991).

14. P. Claeson, P. Rådström, O. Sköld, A. Nilsson and S. Höglund, Phytother. Res., 6, 94 (1992).

15. S.T. Chang and P.F. Chen, S.Y. Wang and H.H. Wu, J. Med. Entomol., 38, 455 (2001). 